MOL2NET, International Conference Series on Multidisciplinary Sciences

\title{
sciforum
}

\section{A report of congenital adrenal hyperplasia due to $17 \alpha$-hydroxylase deficiency in two 46,XX sisters}

Fernando Espinosa-Herrera ${ }^{\mathrm{a}, c^{*}}$, Estefanía Espín ${ }^{\mathrm{a}}$, Ana M. Tito-Álvarez ${ }^{\mathrm{b}}$, LeonardoJ Beltrán ${ }^{\mathrm{a}}$, Diego Gómez-Correa ${ }^{\mathrm{a}}$, German Burgos ${ }^{\mathrm{a}}$, Arianne Llamos ${ }^{\mathrm{d}}$, Camilo Zurita ${ }^{\mathrm{e}}$, Samantha Rojas ${ }^{\mathrm{f}}$, Iván Dueñas-Espín ${ }^{\mathrm{g}}$, Kenny Cueva-Ludeña ${ }^{\mathrm{h}}$, Jorge Salazar-Vega ${ }^{\mathrm{a}, \mathrm{i}}$, and, Jorge Pinto-Basto

${ }^{a}$ Escuela de Medicina, Facultad de Ciencias de la Salud, Universidad de las Américas (UDLA) - Quito, Ecuador; ${ }^{b}$ Escuela de Enfermería, Facultad de Ciencias de la Salud, Universidad de las Américas (UDLA) - Quito, Ecuador; ${ }^{c}$ Sociedad Ecuatoriana de Medicina Familiar (SEMF); Hospital Vozandes Quito; ${ }^{d}$ Universidad Internacional del Ecuador (UIDE), Facultad de Ciencias Médicas, de la Salud y de La Vida, Escuela de Odontología; ${ }^{e}$ Unidad de Investigaciones en Biomedicina.

Zurita\&Zurita Laboratorios, Cátedra de Inmunología. Facultad de Medicina. Universidad Central del Ecuador (UCE) - Quito, Ecuador; ${ }^{f}$ Hospital Isidro Ayora de Loja. Ministerio de Salud Pública del Ecuador; ${ }^{g}$ Instituto de Salud Pública, Facultad de Medicina, Pontificia Universidad Católica del Ecuador, Quito, Ecuador; ${ }^{h}$ Hospital General Docente de Calderón. Ministerio de Salud Pública del Ecuador; ${ }^{i}$ Hospital Eugenio Espejo. Ministerio de Salud Pública del Ecuador; ${ }^{j}$ Molecular Diagnostics and Clinical Genomics Laboratories, CGC Genetics, Porto, Portugal.

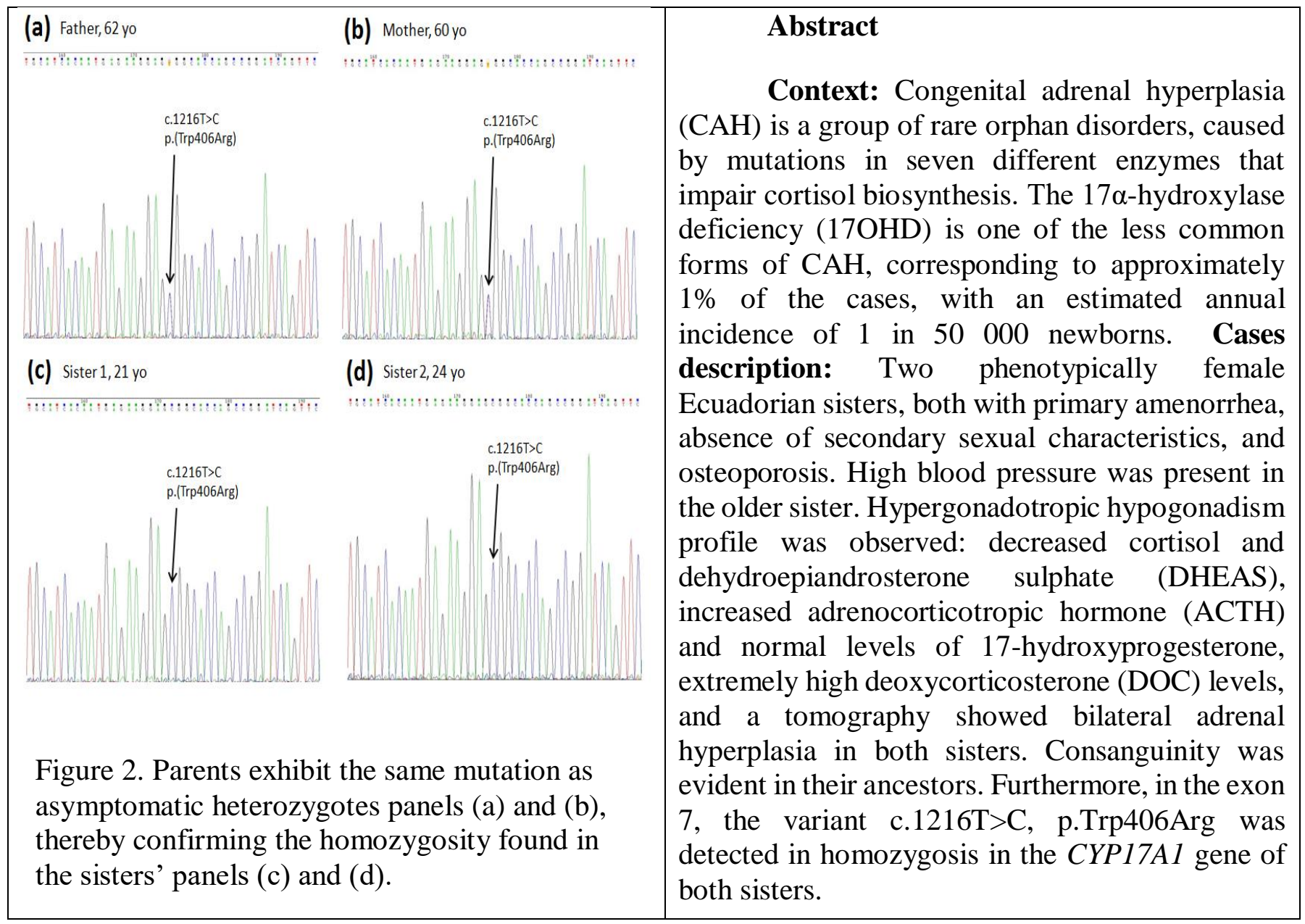


Conclusion: We report a homozygous missense mutation in the CYP17A1 gene causing 17OHD in two sisters from Loja, Ecuador. According to the authors, this is the first time such deficiency and mutation are described in two members of the same family in Ecuador.

Keywords: Congenital adrenal hyperplasia, 17 alpha hydroxylase deficiency, sisters, consanguineous family.

\section{References}

1 Oh YK, Ryoo U, Kim D, Cho SY, Jin DK, Yoon BK, Lee DY, Choi D. 17 $\alpha-$ hydroxlyase/17, 20-lyase Deficiency in Three Siblings with Primary Amenorrhea and Absence of Secondary Sexual Development. J Pediatr Adolesc Gynecol 2012;25:e103-5.

2 Fontenele R, Costa-Santos M, Kater CE. 17A-Hydroxylase Deficiency Is an Underdiagnosed Disease. High Frequency of Misdiagnoses in a Large Cohort of Brazilian Patients. Endocr Pract 2017;24:EP171987.OR.

3 Hannah-Shmouni F, Chen W, Merke DP. Genetics of Congenital Adrenal Hyperplasia. Endocrinol Metab Clin North Am 2017;46:435-58.

4 Grumbach M, Hughes I, Conte F. Williams Textbook of Endocrinology. Larsen PR, Kronenb. HM, Melmed S, Ed. Williams Textb. Endocrinol. 10th ed., Philadelphia: Saunders: 2003, p. 842-1002.

5 Carvalho LC de, Brito VN, Martin RM, Zamboni AM, Gomes LG, Inácio M, Mermejo LM, Coeli-Lacchini F, Teixeira VR, Gonçalves FT, Carrilho AJF, Del Toro Camargo KY, Finkielstain GP, Taboada GF, Frade Costa EM, Domenice S, Mendonca BB. Clinical, hormonal, ovarian, and genetic aspects of 46,XX patients with congenital adrenal hyperplasia due to CYP17A1 defects. Fertil Steril 2016;105:1612-9.

6 Costa-Santos M, Kater CE, Auchus RJ. Two Prevalent CYP17 Mutations and Genotype-Phenotype Correlations in 24 Brazilian Patients with 17-Hydroxylase Deficiency. J Clin Endocrinol Metab 2004;89:49-60.

7 Breder ISS, Garmes HM, Mazzola TN, MacIel-Guerra AT, De Mello MP, GuerraJúnior G. Three new Brazilian cases of 17 $\alpha$-hydroxylase deficiency: Clinical, molecular, hormonal, and treatment features. J Pediatr Endocrinol Metab 2018;31:937-42.

8 Santangelo R, González-Andrade F, Børsting C, Torroni A, Pereira V, Morling N. Analysis of ancestry informative markers in three main ethnic groups from Ecuador supports a trihybrid origin of Ecuadorians. Forensic Sci Int Genet 2017;31:29-33.

9 Homburger JR, Moreno-Estrada A, Gignoux CR, Nelson D, Sanchez E, OrtizTello P, Pons-Estel BA, Acevedo-Vasquez E, Miranda P, Langefeld CD, Gravel S, AlarcónRiquelme ME, Bustamante CD. Genomic Insights into the Ancestry and Demographic History of South America. PLoS Genet 2015;11:1-26.

10 Paz-y-Miño C, Beaty D, López-Cortés A, Proaño I. Frequency of GJB2 and del(GJB6-D13S1830) mutations among an Ecuadorian mestizo population. Int J Pediatr Otorhinolaryngol 2014;78:1648-54.

11 Teeuw ME, Hagelaar A, Ten Kate LP, Cornel MC, Henneman L. Challenges in the care for consanguineous couples: An exploratory interview study among general practitioners 
and midwives. BMC Fam Pract 2012;13:1.

12 Moreira AC, Leal AMO, Castro M. Characterization of adrenocorticotropin secretion in a patient with 17 $\alpha$-hydroxylase deficiency. J Clin Endocrinol Metab 1990;71:86-91.

13 Richards S, Aziz N, Bale S, Bick D, Das S, Gastier-Foster J, Grody WW, Hegde M, Lyon E, Spector E, Voelkerding K, Rehm HL, ACMG Laboratory Quality Assurance Committee. Standards and guidelines for the interpretation of sequence variants: a joint consensus recommendation of the American College of Medical Genetics and Genomics and the Association for Molecular Pathology. Genet Med 2015;17:405-23.

14 Werck-reichhart D, Feyereisen R. Protein family review Cytochromes P450 : a success story. Genome Biol 2000:1-9.

15 Costa-Santos M, Kater CE, Auchus RJ. Two Prevalent CYP17 Mutations and Genotype-Phenotype Correlations in 24 Brazilian Patients with 17-Hydroxylase Deficiency. J Clin Endocrinol Metab 2004;89:49-60.

16 Kardelen, A.D., Toksoy, G., Baş, F., Abalı, Z.Y., Gençay, G., Ş. P, R. B, Altunoğlu, U., Ş. A, A. N, O. U, B. K, S. B, F. D. A rare cause of congenital adrenal hyperplasia: Clinical and genetic findings and follow-up characteristics of six patients with 17-hydroxylase deficiency including two novel mutations. JCRPE J Clin Res Pediatr Endocrinol 2018;10:20615.

17 Yanase T, Imai T, Simpson ER, Waterman MR. Molecular basis of $17 \alpha-$ hydroxylase/17,20-lyase deficiency. J Steroid Biochem Mol Biol 1992;43:973-9.

18 Fernández-Cancio M, García-García E, González-Cejudo C, Martínez-Maestre MA, Mangas-Cruz MA, Guerra-Junior G, Pandi De Mello M, Arnhold IJP, Nishi MY, Bilharinho Mendonça B, García-Arumí E, Audí L, Tizzano E, Carrascosa A. Discordant Genotypic Sex and Phenotype Variations in Two Spanish Siblings with 17 $\alpha$-Hydroxylase/17,20-Lyase Deficiency Carrying the Most Prevalent Mutated CYP17A1 Alleles of Brazilian Patients. Sex Dev 2017;11:70-7.

19 Bee YM, Manju C, Papari-Zareei M, Auchus RJ. Phenotypic variation in a Chinese family with 46,XY and 46,XX 17 $\alpha$-hydroxylase deficiency. Gynecol Endocrinol 2012;28:322-5.

20 Wang YP, Zhao YJ, Zhou GY, He B. CYP17A1 gene mutations and hypertension variations found in 46, XY females with combined 17 $\alpha$-hydroxylase/17, 20-lyase deficiency. Gynecol Endocrinol 2014;30:456-60.

21 Martinez-Arguelles DB, Papadopoulos V. Epigenetic regulation of the expression of genes involved in steroid hormone biosynthesis and action. Steroids 2010;75:467-76.

22 Benetti-Pinto CL, Vale D, Garmes H, Bedone A. 17-Hydroxyprogesterone deficiency as a cause of sexual infantilism and arterial hypertension: Laboratory and molecular diagnosis - a case report. Gynecol Endocrinol 2007;23:94-8.

23 Auchus RJ. Steroid 17-Hydroxylase and 17,20-Lyase Deficiencies, Genetic and Pharmacologic. J Steroid Biochem Mol Biol 2017;165:71-8.

24 Richard-Eaglin A. Male and Female Hypogonadism. Nurs Clin North Am 2018;53:395-405. 